\title{
Tradicijsko lončarstvo ručnoga kola iz Potravlja u Muzeju Cetinske krajine - Sinj
}

- Tema ovoga rada je tradicijsko lončarstvo ručnoga kola iz Potravlja, aktivnoga centra lončarstva ovog tipa koje je uvršteno na Listu zaštićene nematerijalne baštine Republike Hrvatske. Temeljem predmeta koji su dio Etnografske zbirke u Muzeju Cetinske krajine - Sinj, nastojat će se prikazati umijeće izrade seoskih majstora lončara te uporaba ovih predmeta u svakodnevici ruralnoga dalmatinskog zaleđa u 19. te prvoj polovici 20. stoljeća. Svaki od ovih predmeta svojevrsni je dokument i svjedok prošlosti življenja u Cetinskoj krajini, ali i jedan od nositelja identiteta stanovnika Potravlja i danas, budući da se ova tradicija održala i u sadašnjici.

Ključne riječi: Muzej Cetinske krajine - Sinj

muzejske zbirke, lončarstvo, Potravlje

\section{ETNOGRAFSKA ZBIRKA MUZEJA CETINSKE KRAJINE - SiNJ}

Muzej Cetinske krajine - Sinj (dalje u tekstu MCK - Sinj) osnovan je 1956. godine kao Gradski muzej - Sinj. S obzirom da je djelatnost institucije obuhvaćala mnogo šire područje od grada Sinja, Muzej 1963. godine mijenja ime u Muzej Cetinske krajine - Sinj.

Prema vrsti građe koju čuva Muzej je opći te regionalni prema teritorijalnom opsegu obavljanja muzejske djelatnosti. Kao institucija MCK - Sinj je središnje mjesto istraživanja i prezentiranja bogate kulturno-povijesne baštine i nasljeđa Sinja i Cetinske krajine. Fundus MCK - Sinj raspoređen je u 12 muzejskih zbirki: Arheološka zbirka, Numizmatička zbirka, Kulturno-povijesna zbirka, Etnografska zbirka, Prirodoslovna zbirka, Zbirka oružja, Zbirka odlikovanja, medalja i plaketa, Zbirka fotografija i fotografskoga 
pribora, Zbirka dokumenata, Zbirka razglednica, Zbirka plakata te Umjetnička zbirka. Što se tiče stalnoga postava u prostoru MCK - Sinj izložena je Arheološka i Umjetnička zbirka, dok su u prizemlju objekta i lapidariju izloženi kameni spomenici iz različitih stilskih razdoblja.

Etnografska zbirka nije dio stalnoga postava Muzeja i smještena je u čuvaonicama, osim maloga dijela koji je privremeno izložen u galerijskom prostoru. Zbirka sadrži oko 600 predmeta, a najveći dio se odnosi na tradicijsko odijevanje stanovništva Cetinske krajine, a vrijedan dio Zbirke čini tradicijski nakit. Preostali predmeti svjedoče o gospodarskim i stambenim okolnostima ovoga područja u 19. i prvoj polovici 20. stoljeća. Ovaj rad ${ }^{2}$ obrađuje dio Etnografske Zbirke MCK - Sinj koji tematizira uporabnu i gospodarsku ulogu lončarstva u Cetinskoj krajini u životu stanovnika ovoga podneblja u 19. i 20. stoljeću, ali nastoji dati uvid i u aktualno stanje lončarstva ručnoga kola u Potravlju.

\section{TRADICIJSKO LONČARSTVO RUČNOGA KOLA}

U hrvatskoj etnologiji razlikujemo tri tipa lončarstva prema tehnici rada, a to su: lončarstvo bez uporabe lončarskoga kola, lončarstvo ručnoga te lončarstvo nožnoga lončarskog kola. O lončarstvu bez uporabe lončarskoga kola ima malo podataka, a lončarstvo ručnoga i nožnoga kola u mnogim se mjestima održalo do sredine 20. stoljeća. Ručno se kolo pretežno održalo u jadranskom i dinarskom kulturnom arealu, dok je nožno kolo zastupljeno u panonskom (usp. Randić 1999: 11).

Na nožnome lončarskom kolu podloga za oblikovanje spojena je osovinom s donjom kružnom pločom, što je omogućivalo lončaru da pokretanjem donje plohe (bosom) nogom stavlja u vrtnju i gornju plohu pa su mu za rad ostale slobodne obje ruke. Ti su lončari upotrebljavali masniju glinu, pa nije bio potreban dodatak, a oblikovali su "izvlačenjem" od jedne grude sirovine pri brzoj vrtnji. Stjenke posuda su tanje, geometrijski i cvjetni ukrasi izvedeni bojom, nanesenom kistom. Pečenje se obavljalo u posebnim, zatvorenim lončarskim pećima. Dio se proizvoda i ocakljivao bojenjem u otopini metalnih oksida (žuto, zeleno, smeđe), što je zahtijevalo još jedno pečenje. ${ }^{3}$

Početkom 20. stoljeća ustanovljeno je nekoliko centara lončarstva ručnoga kola na području južne Hrvatske te u unutrašnjosti Dalmacije, koje odlikuju predmeti od neglazirane gline: izrađeni na ručnome lončarskom kolu, sušeni na zraku te potom pečeni na otvorenoj vatri (usp. Vojnović-Traživuk 2009: 101). Izrada lončarskih proizvoda na ručnome lončarskom kolu stara je tehnika poznata još u pretpovijesno doba. Iako su se s vremenom lončarske tehnike razvijale i usavršavale, ovaj je način rada, korištenje posebne mješavine gline i usitnjenoga kamena, uporaba niskoga kola pokretanoga rukom i pečenje posuda na otvorenoj vatri, opstao u nekim područjima svijeta sve do kraja 20.

1 http://www.mck-sinj.hr/o-muzeju1 (pristup 1. studenog 2016.).

2 Rad je primarno nastao za potrebe stručnoga ispita za muzejsko zvanje kustos pri Muzejskom dokumentacijskom centru pod mentorstvom dr. sc. Iris Biškupić Bašić, muzejske savjetnice Etnografskoga muzeja u Zagrebu, na čiji sam poticaj i odlučila objaviti rad te joj zahvaljujem ovom prigodom.

3 Leksikografski zavod Miroslav Krleža, http://www.enciklopedija.hr/natuknica.aspx?id=37080 (pristup 5. studenog 2016). 
stoljeća, a ponegdje se održao do danas (Randić 2014: 105). Lončarstvom su se bavili muškarci, i to kao dodatnim zanimanjem, a u prošlosti su nerijetko svoje proizvode mijenjali za žito ("koliko žita stane u lonac - nosi!") (usp. Petrić 1979.; Vojnović-Traživuk 2009.) Sredinom prošloga stoljeća industrijalizacija uzima maha, a usporedno s njom se odvija i proces deruralizacije i migracije seoskoga stanovništva ka gradovima. Rezultat tih procesa jest i napuštanje tradicijskih zanata zbog lakše dostupnosti industrijski proizvedenih artikala te podizanja kvalitete života. Napuštanjem otvorenih ognjišta, bitno se umanjuje potreba za lončarskim proizvodima, dovodeći posljedično do rapidnoga smanjenja izrade lončarije. ${ }^{4}$ Krajem druge polovice 20 . stoljeća preostala su tek dva aktivna centra lončarstva ručnoga lončarskog kola u Hrvatskoj, u čijoj je ponudi značajno mjesto zauzela proizvodnja suvenira (pitari, amfore, umanjene peke, bakre, lonci, teče), uz tradicionalne proizvode. ${ }^{5}$

\section{LONČARSTVO RUČNOGA KOLA U POTRAVLJU KRAJ SINJA}

O lončarskoj djelatnosti na području Cetinske krajine piše već Alberto Fortis u svom "Putopisu po Dalmaciji", objavljenom 1774. godine, a potvrdu njegovim navodima daje i mladi Sinjanin Ivan Lovrić u svom djelu "Bilješke o putu po Dalmaciji opata Alberta Fortisa" iz 1776. godine. Nadalje, iz njihovih djela iščitavamo kako je lončarstvo bila uobičajena dodatna muška aktivnost za tzv. morlačko stanovništvo, zbog isključive upotrebe glinenoga posuđa među ruralnim stanovništvom. Posuđe se mahom mijenjalo za žito ili se prodavalo po sajmovima. Potvrdu o lončarskoj djelatnosti u Cetinskoj krajini može se naći i kod Antuna Matasa (usp. Petrić 1979: 351-352).

Podrobni opis lončarske aktivnosti u Cetinskoj krajini kroz posljednja tri stoljeća donosi Mario Petrić, ugledni etnolog iz Sinja, koji uspoređuje Fortisove i Lovrićeve zapise sa stanjem sredinom 20. stoljeća. Terenska istraživanja provodila je i Jelena Gamulin te je detaljno zabilježen proizvodni proces te terminologija. Poučavanjem lončarstva u Potravlju bavila se i Branka Vojnović-Traživuk, viša kustosica Etnografskoga muzeja Split, na temelju terenskoga rada Jelene Gamulin te fundusa Etnografskoga muzeja Split.

Danas se lončarskom djelatnošću u Potravlju bave sinovi Jure Knezovića (1933. - 2012.), Ivan (rođ. 1962.) te Filip "Pile" (rođ. 1965.), uz potporu Ministarstva kulture. Lončarstvo ručnoga kola u Potravlju ima status kulturnoga dobra te je 2013. godine upisano na Listu zaštićenih nematerijalnih kulturnih dobara Republike Hrvatske, uz podršku i preporuku MCK - Sinj. Lončarstvo, odnosno bakrarstvo ${ }^{6}$ muška je djelatnost koja se prenosi s oca na sina, a tako je ostalo i do danas. Dio prezentacije široj javnosti odvija se i kroz edukativne radionice koje priređuje gosp. Ivan Knezović iz Potravlja, a koji se lončarstvom bavi dvadeset godina. Radionice se održavaju uz potporu Ministarstva kulture i Turističke zajednice Grada Sinja. Tim se aktivnostima nastoji potaknuti interes

4 Vidi više u: Randić, 2014.

5 Uz Potravlje kraj Sinja, preostali aktivni centar lončarstva ručnoga lončarskog kola je Veli Iž, čiji je status ugrožen nakon smrti posljednjega lončara, Predraga Petrovića 2015. godine.

6 Lončare u Cetinskoj krajini nazivaju bakrarima, po posudi za kuhanje, bakri, koja se najviše proizvodila u prošlosti. 
(ponajprije) lokalnoga stanovništva i svih zainteresiranih za tradicijsko lončarstvo i ukazati na bogatstvo tradicijske kulture Cetinske krajine. Polaznici radionice su dobili priliku vidjeti proizvodni proces, dok se autorica ovog teksta i sama okušala u umijeću izrade lončarskih proizvoda.

Glina (gnjila, zemlja) se miješa s vrstom (kalcitom), koja je vezivno tijelo te omogućuje pečenje gline na visokim temperaturama. Prema kazivanju Ivana Knezovića, idealan omjer gline i vrste je 2:1. Navodi i da postoji više tipova vrsta, no on koristi kristaliziranu, koja se danas usitnjava suvremenim strojevima. Osim vrste, kao vezivno tkivo upotrebljava se i pržina (usitnjen pijesak), najčešće pri izradi posuda za cvijeće, pitara, zbog stalnoga doticaja s vlagom. Sama glina se dobiva iskapanjem bagerom te prevozi autom, dok se u prošlosti kopala ručno, a za prijevoz su se koristile mazge. Glina, koje na ovom području ima u izobilju, glavni je preduvjet za održavanje ove djelatnosti do današnjih dana. Najzastupljenija vrsta gline na ovom prostoru je smeđa, a osim nje nalazimo i crvenu. Kazivač navodi kako i danas upotrebljava glinu koja se nalazi u Hrvacama, odakle je i njegov otac nabavljao. Glina se nakvasi i umiješa s kalcitom, vrstom ili pržinom, te se miješaju bosom nogom, što se naziva kuvanjem zemlje koja na taj način omekša. Prije se zemlja kuhala raspoređena po kozjoj koži, dok se danas koristi šatorsko krilo ili sličan materijal. Modelira se na ručnom lončarskom kolu, čekrku, uz pomoć drvenoga noža, kusture; drvenoga vretena za pravljenje rupica na ušima lonca i krpe; perače koji stoje u posudi s vodom, gladarici. Nekada se za krpu, peraču, upotrebljavao komad platna, no danas se koriste i drugi materijali koji su (poželjno) malo grublji. Nakon što je sve spremno za modeliranje, građenje, lončar uzima grudu gline te je spljeska do željene veličine i postavi na kolo koje je prethodno posuto vrstom, kako bi se izbjeglo lijepljenje dna posude za kolo. Uz pomoć kusture, koju drži u jednoj ruci, laktom prislonjenu na nogu (kako bi se osigurala statičnost ruke), ocrtava kružnicu na spljeskanoj glini, dok drugom rukom pokreće kolo. Potom se dno prignječi na četiri strane. Lončar sada pravi valjuške, turice, od smjese gline i kalcita te ih gnječi i spaja na donji dio, stvarajući stijenke lonca. Dno se učvrsti s još gline, no iznimno je bitno da bude ravnomjerno raspoređeno, u protivnom pri pečenju puca. Nakon dna, oblikuje se stijenka posude, koja ne smije biti ni pretanka ni predebela (optimalna debljina stijenke je $0,7-0,8 \mathrm{~cm}$ ). Stijenka posude se ziđa dodavanjem novih valjušaka, red po red do željene visine. Nakon dodavanja valjuška, čekrk se okreće jednom rukom, kako bi se postigao pravilan oblik posude, dok istodobno drugom rukom kusturom (drvenim nožem) poravnavamo izvanjski dio posude te spajamo valjuške, bez vidljivih prijelaza. Potom se uzima perača, krpica za pelišenje posude, koja se namoči i pomaže pri oblikovanju posude. Tijekom izrade stijenke, palac se moči i njime se pritišče posuda iznutra, kako bi se glina što bolje povezala. Proces izrade trbuha posude naziva se kuljenje. ${ }^{7}$ Glinom se može manipulirati sve dok u njoj ima vlage. Nakon oblikovanja posude, dodaju se ručke, uglavnom od grla do sredine trbuha posude. Ukoliko se izrađuje i poklopac, potrebno je izmjeriti dimenzije posude dok se još nije osušila i uzeti u obzir da se u procesu sušenja glina suzi do $8 \mathrm{~mm}$. Tehnike ukrašavanja posuda su jednostavne i baziraju se

$7 \quad$ Kuljava žena jedan je od lokalnih izraza za trudnicu. 
urezivanju jednostavnijih linija (jednostavni geometrijski ukrasi), većinom za izradu pitara, posuda za cvijeće, a ostale posude se ne običavaju ukrašavati.

Nakon obrade, potrebno je dobro osušiti posudu prije stavljanja na vatru. Danas se, zbog izrade veće količine proizvoda, (u prošlosti je većina domaćinstava izrađivala manji broj posuda za vlastite potrebe), posude suše ljeti, budući da je potrebna veća toplina kako bi vlaga iščezla iz gline. Posuđe se peče na lomači koja se napravi na čistini zvanoj žernica: drveni ugljen se na jednom kupu užari i rasprostre na onoliku širinu koliko odgovara količini posuda. Posude se slažu preokrenute i ispunjavaju prostor pokriven žeravicom. Na preokrenute posude poslaže se novi red cjepanica i na njih se slažu lonci. Peke se prislanjaju uz bok poslaganih lonaca te se oko njih slažu duge cjepanice. Pečenje traje dok posude ne poprime crvenkastu boju, ${ }^{8}$ nakon čega se vade dugom motkom, sojom. Iznimno je važno pravilno postaviti posude na vatru, treba znati optimalan položaj i uzeti u obzir širenje gline u vatri ili posude popucaju u vatri. Posljednji korak pri izradi posude jest kaljenje, tj. premazivanje lončarije razmućenim pšeničnim brašnom s pomoću krpe koja se nakon toga kratko vraća na žeravicu dok kalivo ne poprimi tamnu boju (usp. Petrić 1979: 358 i Vojnović-Traživuk 2009: 105). ${ }^{9}$

Proizvodnja glinenoga posuđa u Potravlju danas se svodi na produkciju suvenira, posuda za cvijeće (pitara) te posebice peka, za koju se tvrdi da hrani pruža izvanredan okus te se povezuje s konceptom zdrave prehrane (usp. Vojnović-Traživuk 2005: 157). Posuđe se prodaje i na pučkim slavljima, dernecima te po narudžbi. Opažaju su procesi retradicionalizacije i popularizacije segmenata narodne kulture, posebice u turizmu i ugostiteljstvu, stoga tradicionalne rukotvorine često možemo pronaći u objektima toga tipa diljem Dalmacije (ponajprije konobama, koje se nadahnjuju idejom Mediterana kakav je nekad bio pri turističkoj promociji Primorja), ${ }^{10}$ što nam potvrđuje i gosp. Knezović.

\section{TRADICIJSKO LONČARSTVO RUČNOGA KOLA POTRAVLJA U MCK - SINJ}

Etnografska zbirka Muzeja Cetinske krajine - Sinj počinje se prikupljati od 1980-ih godina, a jedan od segmenata tradicijskoga života koje štiti od zaborava jest i lončarstvo ručnoga kola u Potravlju, koje je dobilo status kulturnoga dobra zahvaljujući, među ostalim, i zalaganju Muzeja što nas upućuje na važnu ulogu koju Muzej ima za kontinuitet tradicije te svijest o očuvanju kulturne baštine.

U daljnjem tekstu će se obrađivati nekoliko predmeta koji su darovanjem Etnografske zbirke Župnoga ureda Sv. Vida u Zelovu pripojeni Etnografskoj zbirci Muzeja Cetinske krajine - Sinj. Izlaskom na teren utvrđeno je kako lončarska aktivnost nije bila zastu-

$8 \quad$ Vidi više u Petrić, 1979.

9 Cjelokupni proces izrade posuđa na ručnom lončarskom kolu može se pogledati na promotivnom videouratku Turističke zajednice grada Sinja, https://www.youtube.com/watch?v= gSVxHTm7feM (pristup 5. studenog 2016).

10 Osamdesetih i devedestih godina 20. stoljeća došlo je do masovnoga bacanja tradicijskih rukotvorina iz 19. te prve polovice 20. stoljeća, da bi se u posljednjem desetljeću to stanje promijenilo te se iste koriste pri dekoraciji prostorija u danas popularnom etnodizajnu. 
pljena na Zelovu (što je bila početna premisa), unatoč pronalasku ručnoga lončarskog kola te nekolicine posuda, nego je trgovinskim putovima došla do Zelova iz Potravlja, koje je otprije poznato kao jedan od centara lončarstva ručnoga kola. Time se otvara i mogućnost novih istraživanja trgovačkoga posredništva između ova dva naselja poznata po rukotvorstvu: zelovski majstori nadaleko su poznati po izradi drvenarije i pribora za pušenje duhana, dok su potravski opskrbljivali široko dalmatinsko područje svojim posudama. Osim posuda, Muzeju je darovano i ručno lončarsko kolo koje je vjerojatno starije izrade (početak 20. stoljeća), budući da panj, senj koji pridržava čekrk nije račvasto drvo (vidi Sl. 2. i Sl. 3.), nego je jednostavnije konstrukcije. Petrić bilježi gdjegod je rašireno ručno lončarsko kolo, možemo razlikovati dvije vrste kola prema konstrukciji: jedna starija i jednostavnija, a druga mlađa sa složenijom konstrukcijom, a obje vrste imaju svoje varijante. Zajedničko im je okrugla radna ploha pričvršćena s pomoću četiri spojnice za križ (1979: 358).

Potravski majstori bili su poznati po raznovrsnosti svojih proizvoda jer su se prilagođavali zahtjevima ruralne i urbane sredine. Najčešći proizvod koji su proizvodili bila je bakra, posuda za kuhanje po kojoj su dobili nadimak bakrari. Ona je slična loncu, osim što ima dva probušena uha kako bi se mogla vješati na lanac iznad ognjišta, komoštre. Proizvod sličan bakri jest bandeua, jedina razlika je u položaju ušiju posude: kod bakre su smještene s usana, grla posude, a kod bandeue uši su smještene sa strana gornje polovice posude, neposredno ispod vrata ${ }^{11}$ (vidi sliku dolje). Uz bakre, najznačajniji proizvodi bili su lonci, što je zbirni naziv za različite posude, s poklopcem ili bez, s jednom ili dvije ručke, različitih veličina i namjena. Osim bakri i lonaca, značajna je i proizvodnja peka, zaobljenoga poklopca s više zemljanih obruča pod kojim se jelo peče dodavanjem žeravice na peku. I danas je jelo pripremljeno na ovaj način posebno cijenjeno u Cetinskoj krajini i dio je tradicionalne gastronomske ponude.

\section{KATALOG}

1. Vrsta/naziv predmeta: Ručno lončarsko kolo (književni naziv), čekrk (dijalektalni naziv)

Mjesto nastanka: Potravlje

Vrijeme nastanka: 1. polovica 20. st.

Materijal/tehnika: drvo, tesanje; drvo, piljenje

Dimenzije: $\mathrm{v}=25 \mathrm{~cm}, \check{\mathrm{s}}=37,5 \mathrm{~cm}$

\section{Inventarna oznaka: MCK-13873}

Kratki opis: Ručno lončarsko kolo, čekrk, sastoji se od više dijelova: kružne drvene ploče koja se naziva čekrk kao i čitava sprava, drvenoga križa, koji je na svojim krakovima pričvršćen za kružnu ploču s pomoću drvenih klinova, tako da čekrk i križ prave nerazdvojni dio. Kroz sredinu križa prolazi osovina, drveni šiljak (kurelj) usađen u panj

11 Prema kazivanju Ivana Knezovića, lončara. 
(senj), podeblje drvo nepravilna oblika radi bolje stabilnosti. Kružna drvena ploča se pokreće rukom. Služi za modeliranje gline (Sl. 2. i Sl. 3.).

2. Vrsta/naziv predmeta: lonac (književni naziv), ruketnjak (dijalektalni naziv)

Vrijeme nastanka: 1 . polovica 20. st.

Mjesto nastanka: Potravlje

Materijal/tehnika: glina, modeliranje; glina, pečenje; kalcit

Dimenzije: $\mathrm{v}=15,5 \mathrm{~cm}$; $\mathrm{v}($ poklopac $)=1,7 \mathrm{~cm} ; \check{\mathrm{s}}=24 \mathrm{~cm}, \mathrm{pr}(\mathrm{obod})=12 \mathrm{~cm}, \mathrm{pr}$ $($ dno $)=12 \mathrm{~cm}$

\section{Inventarna oznaka: MCK-14154}

Kratki opis: Lonac manjih dimenzija. Obod je blago izvijen i iz njega se nadovezuje ručka koja seže do sredine trbuha posude. Vrat je kratak i blago uvučen, bez izrazitoga prijelaza prema obodu i ramenu posude. Trbuh posude je blago zaobljen. Dno je kružno i ravno. Lonac je debljih stijenki, smeđe boje. Izrađen je od gline s primjesom kalcita. Keramika je čvrsta, dobre kakvoće, poluuglačane površine. Lonac se zatvara okruglim poklopcem iste teksture koji je blago udubljen, a na sredini ima manju ručku stožastoga oblika. Služio je za kiseljenje mlijeka (Sl. 4. i Sl. 5.).

3. Vrsta/naziv predmeta: posuda za kuhanje (književni naziv), bandeua (dijalektalni naziv)

Vrijeme nastanka: 1 . polovica 20. st.

Mjesto nastanka: Potravlje

Materijal/tehnika: glina, modeliranje; glina, pečenje, željezna žica

Dimenzije: $\mathrm{v}=19,3 \mathrm{~cm}$; $\mathrm{v}(\mathrm{s}$ ručkom) $=38 \mathrm{~cm}$; pr (obod) $=14 \mathrm{~cm} ; \mathrm{pr}($ trbuh $) 60 \mathrm{~cm}$; $\operatorname{pr}(\mathrm{dno})=13 \mathrm{~cm}$

\section{Inventarna oznaka: MCK-14155}

Kratak opis: Posuda za kuhanje, srednjih dimenzija. Obod je blago izvijen, po sredini se nalazi blago izvučeni izljev. Obod je okrhnut na više mjesta. Vrat je kratak i blago uvučen, bez izrazitoga prijelaza prema obodu i ramenu posude. Gornji dio tijela posude je poluloptastoga oblika, a donji stožasti i završava ravnim, okruglim dnom. Na gornjem dijelu tijela nalaze se uši koje prelaze obod posude, a kroz koje je provučeno povrstalo, povrslo (žica). Sa stražnje strane gornjega dijela nalazi se izvijena ručka koja ne prelazi obod. Posuda je debljih stijenki, crne boje proizašle od čađe. Izrađen je od gline s primjesom kalcita. Keramika je osrednje kakvoće, hrapavije površine (Sl. 6. i Sl. 7.). 


\section{ZAKLJUČAK}

Lončarstvo ručnoga kola u Cetinskoj krajini ima dug kontinuitet, no od mnogih lončarskih centara aktivan je ostao samo onaj u Potravlju, gdje se lončarskom djelatnosti na ručnom kolu bave sinovi pok. Jure Knezovića (1933. - 2012.), Ivan (rođ. 1962.) i Filip (rođ. 1965.), nastavljajući tako obiteljsku tradiciju koja prelazi s oca na sina. Tradicijsko lončarstvo ručnoga kola iz Potravlja proglašeno je kulturnim dobrom te je upisano na Listu zaštićenih nematerijalnih kulturnih dobara Republike Hrvatske 2013. Time je potvrđena njegova vrijednost te su stvorene predispozicije da se tradicija nastavi i u budućnosti. S obzirom na to da je Potravlje jedini preostali aktivni centar lončarstva ručnoga kola u Republici Hrvatskoj, ističe se važnost proučavanja ove tematike i prezentiranja ovoga dijela baštine kako bi se sačuvala od zaborava i omogućio njezin kontinuitet, čemu zasigurno doprinose i muzejske djelatnosti čuvanja, izlaganja i komunikacije. Muzej Cetinske krajine - Sinj jedna je od kulturnih institucija čiji fundus, među ostalim, daje uvid i u tradicijsko umijeće lončarstva ručnoga kola.

\section{KAZIVAČI:}

Ivan Knezović pok. Jure, rođ. 1962. god., iz Potravlja (lončar)

\section{LITERATURA I IZVORI:}

PETRIĆ, Mario. 1979. "Lončarska tradicija u Cetinskoj krajini". U Zbornik Cetinske krajine: Ivan Lovrić i njegovo doba, Milivoj Čatipović (ur.). Sinj: Kulturno društvo "Cetinjanin", 351.-363.

RANDIĆ, Mirjana. 1999. "Svi lički lončari". Etnološka tribina 22/29: 11-23.

RANDIĆ, Mirjana. 2014. "Lončarska tradicija crikveničkog područja". Vinodolski zbornik 15: 105-114.

VOJNOVIĆ-TRAŽIVUK, Branka 2009. "Lončarska tradicija u unutrašnjosti Dalmacije". Ethnologica Dalmatica. 17: 101-116.

VOJNOVIĆ-TRAŽIVUK, Branka. 2005. "Zbirka keramike u Etnografskome muzeju Split". Ethnologica Dalmatica 14: 147 - 158.

Facebook: Turist Board Sinj. URL: https://www.facebook.com/pg/visitsinj/photos/?tab =album\&album_id $=1221111451289414$ (pristup 5. 11. 2016.)

Leksikografski zavod Miroslav Krleža. Lončarstvo, tradicijsko . URL:http://www.enciklopedija.hr/natuknica.aspx?id=37080 (pristup 5. 11. 2016.)

Muzej Cetinske krajine - Sinj. O muzeju. URL: http://www.mck-sinj.hr/o-muzeju1 (pristup 1. 11. 2016.)

Muzej Cetinske krajine - Sinj. Etnografska zbirka. URL: http://www.mck-sinj.hr/zbirke-ifondovi/etnografska-zbirka (pristup 1. 11. 2016.)

Youtube video: Tradicijsko lončarstvo ručnoga kola u Potravlju . URL: https://www.youtube. com/watch? $\mathrm{v}=\mathrm{gSVxHTm} 7 \mathrm{feM}$ (pristup 5. 11. 2016.) 
OSTALI IZVORI

Predmetne kartice MCK - Sinj (Etnografska zbirka)

Fotografije muzejskih predmeta Etnografske zbirke MCK - Sinj 